NASA/TM-2010-216216

AIAA-2009-5066

\title{
Thin Film Heat Flux Sensor Development for Ceramic Matrix Composite (CMC) Systems
}

John D. Wrbanek, Gustave C. Fralick, Gary W. Hunter, and Dongming Zhu Glenn Research Center, Cleveland, Ohio

Kimala L. Laster

Sierra Lobo, Inc., Cleveland, Ohio

Jose M. Gonzalez

Gilcrest Electric \& Supply Company, Cleveland, Ohio

Otto J. Gregory

University of Rhode Island, Kingston, Rhode Island 


\section{NASA STI Program . . . in Profile}

Since its founding, NASA has been dedicated to the advancement of aeronautics and space science. The NASA Scientific and Technical Information (STI) program plays a key part in helping NASA maintain this important role.

The NASA STI Program operates under the auspices of the Agency Chief Information Officer. It collects, organizes, provides for archiving, and disseminates NASA's STI. The NASA STI program provides access to the NASA Aeronautics and Space Database and its public interface, the NASA Technical Reports Server, thus providing one of the largest collections of aeronautical and space science STI in the world. Results are published in both non-NASA channels and by NASA in the NASA STI Report Series, which includes the following report types:

- TECHNICAL PUBLICATION. Reports of completed research or a major significant phase of research that present the results of NASA programs and include extensive data or theoretical analysis. Includes compilations of significant scientific and technical data and information deemed to be of continuing reference value. NASA counterpart of peer-reviewed formal professional papers but has less stringent limitations on manuscript length and extent of graphic presentations.

- TECHNICAL MEMORANDUM. Scientific and technical findings that are preliminary or of specialized interest, e.g., quick release reports, working papers, and bibliographies that contain minimal annotation. Does not contain extensive analysis.

- CONTRACTOR REPORT. Scientific and technical findings by NASA-sponsored contractors and grantees.
- CONFERENCE PUBLICATION. Collected papers from scientific and technical conferences, symposia, seminars, or other meetings sponsored or cosponsored by NASA.

- SPECIAL PUBLICATION. Scientific, technical, or historical information from NASA programs, projects, and missions, often concerned with subjects having substantial public interest.

- TECHNICAL TRANSLATION. Englishlanguage translations of foreign scientific and technical material pertinent to NASA's mission.

Specialized services also include creating custom thesauri, building customized databases, organizing and publishing research results.

For more information about the NASA STI program, see the following:

- Access the NASA STI program home page at http://www.sti.nasa.gov

- E-mail your question via the Internet to help@ sti.nasa.gov

- Fax your question to the NASA STI Help Desk at $443-757-5803$

- Telephone the NASA STI Help Desk at 443-757-5802

- Write to: NASA Center for AeroSpace Information (CASI) 7115 Standard Drive Hanover, MD 21076-1320 
NASA/TM-2010-216216

\section{Thin Film Heat Flux Sensor Development for Ceramic Matrix Composite (CMC) Systems}

John D. Wrbanek, Gustave C. Fralick, Gary W. Hunter, and Dongming Zhu Glenn Research Center, Cleveland, Ohio

Kimala L. Laster

Sierra Lobo, Inc., Cleveland, Ohio

Jose M. Gonzalez

Gilcrest Electric \& Supply Company, Cleveland, Ohio

Otto J. Gregory

University of Rhode Island, Kingston, Rhode Island

Prepared for the

45th Joint Propulsion Conference and Exhibit cosponsored by AIAA, ASME, SAE, and ASEE

Denver, Colorado, August 2-5, 2009

National Aeronautics and

Space Administration

Glenn Research Center Cleveland, Ohio 44135 


\section{Acknowledgments}

The authors would like to acknowledge the assistance of Beth Osborn of Sierra Lobo, Inc. supporting the NASA Glenn Research Center (GRC) Test Facilities Operations, Maintenance, and Engineering (TFOME) organization for polishing the $\alpha$-SiC samples, Charles Blaha of Jacobs Technology also supporting the NASA GRC TFOME for general support for the depositions in this effort, and Laura Evans of the NASA GRC Sensors and Electronics Branch for repairing the laser machining system. The NASA Glenn Research Center's ceramic thermocouple development was sponsored by the Aircraft Aging and Durability Project of NASA's Aviation Safety Program, and the application of the ceramic thermocouples on SiC ceramics sponsored by the Supersonics Project of NASA's Fundamental Aeronautics Program, both part of NASA's Aeronautics Research Mission Directorate.

This report contains preliminary findings, subject to revision as analysis proceeds.

This work was sponsored by the Fundamental Aeronautics Program at the NASA Glenn Research Center.

Level of Review: This material has been technically reviewed by technical management.

Available from

NASA Center for Aerospace Information 7115 Standard Drive Hanover, MD 21076-1320
National Technical Information Service 5301 Shawnee Road Alexandria, VA 22312

Available electronically at http://gltrs.grc.nasa.gov 


\title{
Thin Film Heat Flux Sensor Development for Ceramic Matrix Composite (CMC) Systems
}

\author{
John D. Wrbanek, Gustave C. Fralick, Gary W. Hunter, and Dongming Zhu \\ National Aeronautics and Space Administration \\ Glenn Research Center \\ Cleveland, Ohio 44135 \\ Kimala L. Laster \\ Sierra Lobo, Inc. \\ Cleveland, Ohio 44135 \\ Jose M. Gonzalez \\ Gilcrest Electric \& Supply Company \\ Cleveland, Ohio 44135 \\ Otto J. Gregory \\ University of Rhode Island \\ Kingston, Rhode Island 02881
}

\begin{abstract}
The NASA Glenn Research Center (GRC) has an on-going effort for developing high temperature thin film sensors for advanced turbine engine components. Stable, high temperature thin film ceramic thermocouples have been demonstrated in the lab, and novel methods of fabricating sensors have been developed. To fabricate thin film heat flux sensors for Ceramic Matrix Composite (CMC) systems, the rough and porous nature of the CMC system posed a significant challenge for patterning the fine features required. The status of the effort to develop thin film heat flux sensors specifically for use on silicon carbide ( $\mathrm{SiC}$ ) CMC systems with these new technologies is described.
\end{abstract}

\section{Introduction}

To advance knowledge in fundamental aeronautics and develop technologies for safer, lighter, quieter, and more fuel efficient aircraft, instrumentation technologies are being developed by the National Aeronautics and Space Administration (NASA) in support of its mission to pioneer the future in space exploration, scientific discovery, and aeronautics research. These technologies also enable the capabilities for long duration, more distant human and robotic missions for the Vision for Space Exploration.

The NASA Fundamental Aeronautics Program's Supersonics Project is a broad-based effort designed to develop knowledge, capabilities, and technologies supporting all vehicles that fly in the supersonic speed regime, from space vehicles (launch/reentry) to military and commercial transport. A primary goal is to eliminate the barriers that limit efficiency and performance, as well as to mitigate environmental impacts, with practical supersonic cruise vehicles.

To characterize the degradation processes that occur from the harsh hot section conditions, the NASA Aviation Safety Program's Aging Aircraft and Durability (AAD) Project has an effort to develop novel thin film sensor technology for turbine hot section environment. Sensors to measure high temperature and strain are being developed that will allow fabrication of more durable components through models of component characteristics with increased accuracy.

The application of ceramic matrix composites (CMCs) to airframe and propulsion systems will allow higher temperature operation at extended supersonic cruise times, as well as introducing significant weight reduction in components (Ref. 1). Successful implementation of these ceramics requires reliable performance data and life prediction models (Ref. 2). In order to achieve performance goals, innovative environmental barrier coatings (EBCs) for CMC systems are under development by the NASA Glenn Research Center (GRC). These EBCs are required to 
have significantly increased phase stability, lower thermal conductivity, and improved sintering and thermal stress resistance under the engine's high-heat-flux and severe thermal cycling conditions (Ref. 3). Measurements of heat flux and thermal stress of the EBC on CMC systems are necessary for their application to propulsion system components.

The Sensors and Electronics Branch of NASA GRC has an in-house effort to develop thin film sensors for surface measurement in propulsion system research. The sensors include those for strain, temperature, heat flux and surface flow which will enable critical vehicle health monitoring and characterization of components of future space and air vehicles (Ref. 4). These sensors have a wide range of applications and provide unique measurements for high temperature systems.

To enable the development of CMC systems and their resulting contribution to the performance of air and spacecraft, the application of ceramic thin film sensors to CMC components was addressed to allow the required measurements of physical properties and capabilities of those components.

\section{High Temperature Heat Flux Sensor Foundations}

The use of sensors made of thin films has several advantages over wire or foil sensors. Thin film sensors do not require special machining of the components on which they are mounted, and, with thicknesses less than $10 \mu \mathrm{m}$, they are considerably thinner than wire or foils. Thin film sensors are thus much less disturbing to the operating environment, and have a minimal impact on the physical characteristics of the supporting components (Ref. 5).

All heat flux sensors operate by measuring the temperature difference across a thermal resistance. There are various designs of heat flux sensors, such as Gardon gauges, plug gauges, and thin film thermocouple arrays. Thin film heat flux gauges have the advantage of high frequency response and minimal flow disturbance. A thin film heat flux sensor developed at NASA GRC operates by measuring the temperature difference between thin film temperature sensors under different thicknesses of thermal insulating films, as shown in Figure 1 (Ref. 6).

The sensor is typically fabricated as a thermocouple array on the surface of a ceramic material. Because of the small temperature differences involved, and the small output of a single junction, the thermocouples are arranged as a thermopile (Fig. 2). A thin film of a thermal barrier coating (TBC) such as silicon oxide or yttria-stabilized zirconia is sputtered over the pairs in the center of the array to form a cooler region. For an example of the performance of such a sensor, a 40-pair thermocouple thin-film heat flux gauge was demonstrated in an arc-lamp calibration facility with sensitivity of $1.2 \mu \mathrm{V} \cdot\left(\mathrm{W} \cdot \mathrm{cm}^{-2}\right)^{-1}$ and a dynamic frequency response of $3 \mathrm{kHz}$ for temperatures on the surface of the sensors of up to $800^{\circ} \mathrm{C}$ (Ref. 7).

Recently, there has been an increased need for in-situ measurement of high temperature heat flux in aerospace systems development. One example is a two-sided version of a thin film heat flux sensor designed for use in Advanced Stirling Convertor (ASC) Engineering Units for long term duration testing (Fig. 3) (Ref. 8). In characterizing the ASC units, a direct measurement of thermal to electrical conversion efficiency is required. The initial models were fabricated using gold-platinum thermocouples for the nominal $6.6 \mathrm{~W} \cdot \mathrm{cm}^{-2}$ at $850{ }^{\circ} \mathrm{C}$ into the convertors. The next generation of convertors will increase the input to over $950{ }^{\circ} \mathrm{C}$, requiring the use of platinumpalladium thermocouples.

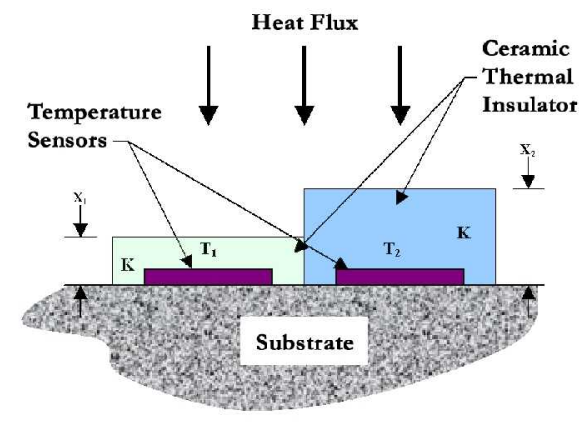

Figure 1.-Thin film heat flux sensor theory of operation.

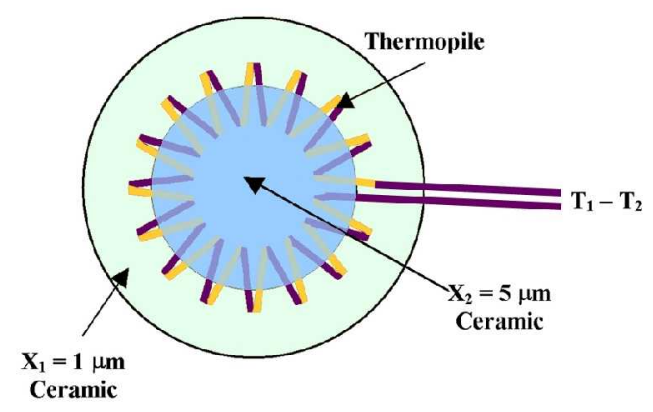

Figure 2.-Thin film thermopile heat flux sensor. 


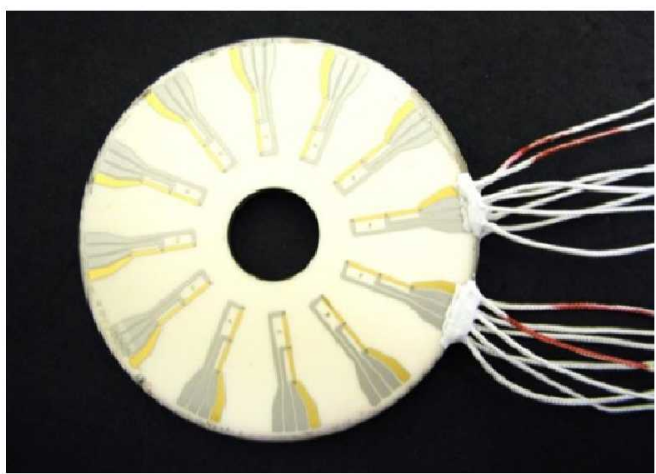

Figure 3.-A $6.66 \mathrm{~cm}$ diameter Au-Pt heat flux sensor for the Advanced Stirling Convertor Development Project.

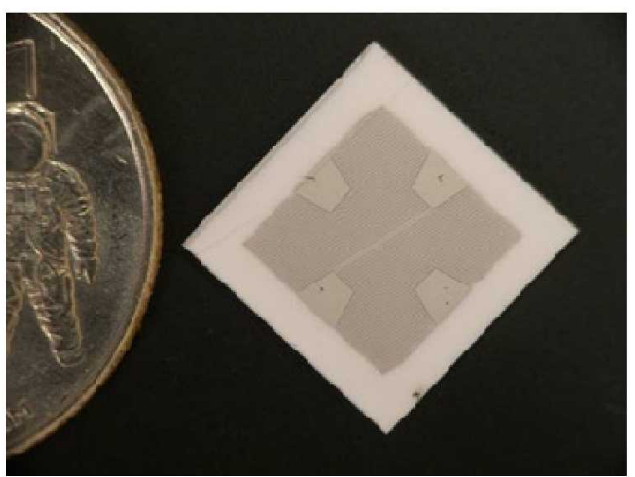

Figure 4.-A $2.4 \mathrm{~cm}$ square heat flux sensor for CEV TPS Heat Shield-to-Backshell Interface Seals Project.

Another example is a heat flux sensor utilizing a platinum resistance bridge instead of a thermopile fabricated for the Crew Exploration Vehicle (CEV) Thermal Protection System (TPS) Heat Shield-to-Backshell Interface Seals project (Fig. 4). The application was as part of an in-situ instrumentation suite for interface gap heating tests with target heat flux exposures of $35 \mathrm{~W} \cdot \mathrm{cm}^{-2}$ and surface temperatures approaching $1350{ }^{\circ} \mathrm{C}$. The sensor in this effort included ceramic packaging and lead wire attachment that would be able to withstand the high temperature of the tests.

The above applications, though using ceramic substrates, progressively approach the limits of metal thin film sensors given the inherent durability of these metallic systems. Ceramic-based sensor systems will be necessary for higher temperature applicators (Ref. 4).

Currently, EBC-CMC systems are under development at GRC for application as high temperature turbine vanes and blades. These systems are tested up to $1700^{\circ} \mathrm{C}$, and sensors fabricated as part of an EBC-CMC system to allow in situ measurements during tests are needed to better characterize these systems. The application of ceramic films as sensors is utilized to satisfy these conditions both from a sensing material and a patterning perspective.

\section{Sensor Material Selection}

For the high temperature environments that the sensor films will experience, the potential for cracking and delamination of the films needs to be considered in selecting appropriate materials due to the thermal expansion mismatch stresses under thermal cycling conditions. Delamination with temperature cycles of films on a substrate is considered a first order effect of mismatches between the two materials' Coefficient of Thermal Expansion (CTE). The intrinsic strength and adhesion of the films to the substrate are also important in designing the sensor systems.

The initial sensor material selection is based on the CTEs of the EBC-CMC system and the film to be used as a sensor. The particular EBC-CMC system being addressed in this effort is a silicon carbide (SiC) CMC material with an aluminosilicate-based EBC (Ref. 9). The thermal expansion of the CMC is approximately $4.4 \times 10^{-6} \mathrm{~K}^{-1}$ (Ref. 10), and the thermal expansion of the natural aluminosilicate crystal composite mullite $\left(3 \cdot \mathrm{Al}_{2} \mathrm{O}_{3}+2 \cdot \mathrm{SiO}_{2}\right)$ is approximately $4.4 \times 10^{-6} \mathrm{~K}^{-1}$ (Ref. 11). Allowing less than a mismatch of typically \pm 30 percent from these values, only materials with thermal expansions in the range of 3.1 to $5.8 \times 10^{-6} \mathrm{~K}^{-1}$ would be practical.

If delamination potential based on CTE was the only criterion, the choices would be limited to tantalum nitride and cermets based on oxides (Ref. 12). However, the adhesion strength of a film on an oxide substrate is determined primarily by the film's ability to form an oxide on the substrate surface rather than the amount of CTE mismatch between the film and substrate (Refs. 13 and 14). Since the EBC can be considered as both an oxide and silicate, all silicides can also be included with the oxides as potential candidates for thin film sensors due the formation of a silicide at the interface of the film, as well as the general passivating silicon oxide coating formed when silicides are exposed to air at high temperature. Of the silicide films, chromium silicide ( $\mathrm{CrSi})$ and molybdenum silicide $(\mathrm{MoSi})$ are seen to be the most attractive due to the high thermoelectric output of $\mathrm{CrSi}$ and high oxidation resistance of MoSi (Ref. 15).

An initial test of the $\mathrm{CrSi}$ and MoSi films as a thermocouple at $800{ }^{\circ} \mathrm{C}$ found that the thickness of the oxide formed on the silicides was greater than the $1 \mu \mathrm{m}$ film thickness after $1 \mathrm{hr}$ exposure. A study of relative oxide thickness for 1-hr air annealing at $400,600,800$, and $1000{ }^{\circ} \mathrm{C}$ was conducted to determine the minimum useful thickness of the silicides. For $1500^{\circ} \mathrm{C}$ exposure, the estimate is that the oxide coating on CrSi would be $2.4 \mu \mathrm{m}$ after 


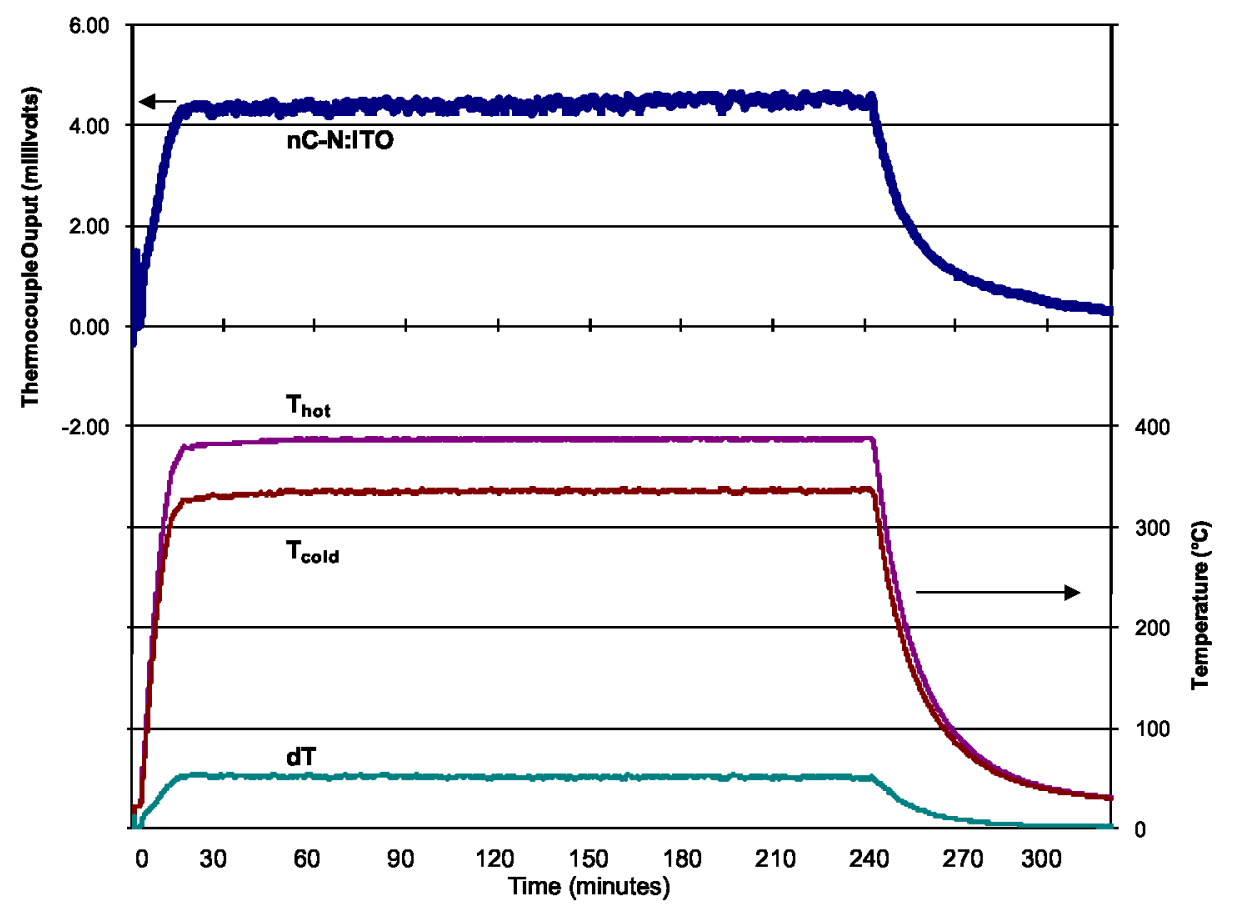

Figure 5.-Time response of the nanocomposite (nC) NiCoCrAlY:AlOx-N:ITO thermocouple with corresponding temperatures.

$1 \mathrm{hr}$. Therefore, the usefulness of these silicides in a thin film sensor at $1500{ }^{\circ} \mathrm{C}$ temperatures is limited to applications where the sensor is embedded in an EBC and protected from further oxidation.

Thermoelectric properties of thermocouples comprised of nitrogen-doped indium-tin oxide (N:ITO) and a nanocomposite film sputtered from a cermet of NiCoCrAlY alloy with 20 percent aluminum oxide (NiCoCrAlY:AlOx) have been reported to produce a linear response with extremely high sensitivity and exhibiting minimal hysteresis (Ref. 16). A NiCoCrAlY:AlOx-N:ITO thermocouple was fabricated as a thermocouple on alumina in the NASA GRC Microfabrication Clean Room. Initial tests showed the 2- $\mu \mathrm{m}$ thick thermocouple stable in air with a $50 \mu \mathrm{V} \cdot \mathrm{K}^{-1}$ sensitivity at $650{ }^{\circ} \mathrm{C}$, compared to the standard platinum-rhodium alloy versus platinum thermocouple (i.e., ANSI Type R) with $12 \mu \mathrm{V} \cdot \mathrm{K}^{-1}$ sensitivity at that temperature. A graph of the results with time is shown in Figure 5.

Based on these results, NiCoCrAlY:AlOx and N:ITO were selected as the basis of heat flux sensors fabricated on EBC-CMC samples.

\section{Sensor Patterning}

Previous work is the basis for this present EBC-CMC sensor pattern development. For example, thin film sensors have been fabricated on advanced SiC-CMC components at GRC for testing to $1100^{\circ} \mathrm{C}$ in jet-fueled burner rigs using thin film Type $R$ thermocouples patterned using shadow masks, shown in Figure 6 (Ref. 17). The application to fabricate fine-line platinum sensors on SiC-CMC also has been demonstrated at GRC in the past, as shown on Figure 7. The surface was prepared for photolithography by filling the surface weave of the CMC with a $\mathrm{SiC}$ paste followed by alumina paste, then lapping and polishing to $1 \mu \mathrm{m}$ roughness after curing.

However, the application of thin film sensors in an EBC-CMC system disallows the use of alumina paste coatings, since their use would modify the very characteristics that the sensors are to measure. Further, the patterning of fine-line thin film sensors is a technical challenge due to the rough nature of the CMC surface and the relatively porous nature of the EBC. The weave of the fibers causes variation of the CMC surface, typically of $\pm 100 \mu \mathrm{m}$, unsuitable for photolithography without smoothing of the $\mathrm{EBC}$ surface. The natural aluminosilicate crystalline mullite is too porous for lift-off patterning of a fine-line sensor using photolithography. Until the EBCCMC systems are to be developed to the point of producing components of smoothness approximating that of polished metal components, alternative techniques will need to be examined. 


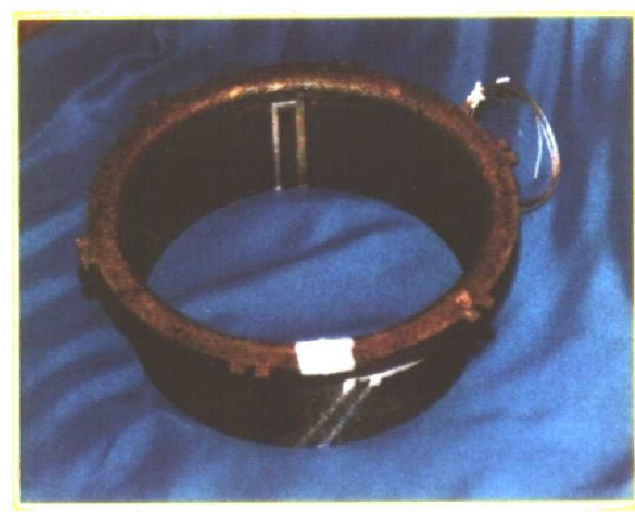

Figure 6.-PtRh/Pt thermocouples shadowmasked on SiC-CMC test component.

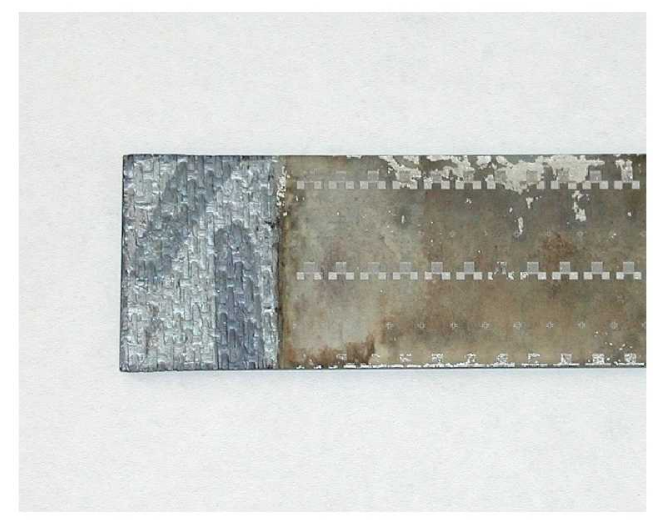

Figure 7.-Fine-lined Pt test sensors patterned on $\mathrm{AlOx} / \mathrm{SiC}$ coated SiC-CMC.

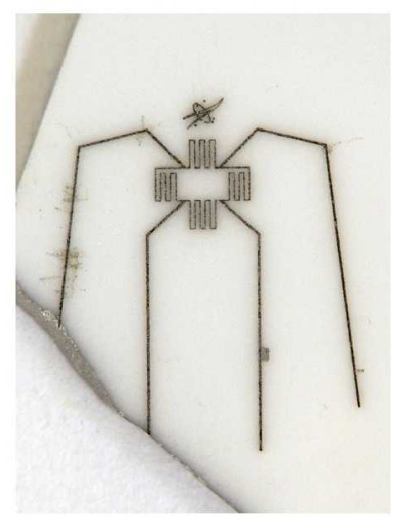

Figure 8.-Laser-patterning on alumina substrate.

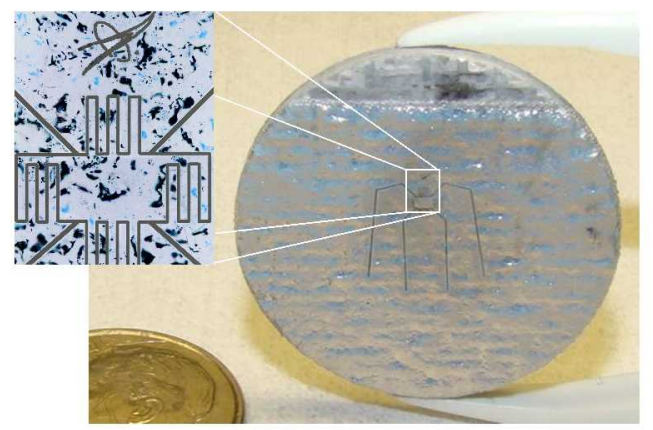

Figure 9.-Laser-patterning sacrificial metal on EBC-CMC

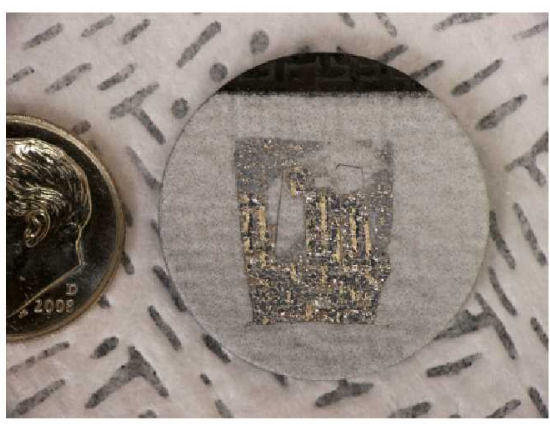

Figure 10.-Post-platinum deposition; failed etch of the sacrificial layer.

One alternative to photolithography that was explored involved using a Nd:YAG laser machining tool. The aluminum sacrificial layer is first deposited, and then a pattern is etched into the sample with the laser through ablation. The pattern is in standard CAD format. The sensor material is deposited, and the sacrificial layer etched away. The result is a fine-line sensor with $30 \mu \mathrm{m}$ line widths without the use of photolithography or photomasks. A sample showing the developed result with platinum film is shown in Figure 8.

The limitation of the technique was demonstrated on an EBC-CMC sample shown in Figures 9 and 10. The sample roughness did not allow the aluminum to lift off cleanly from the surface. Thus, this technique is limited to surfaces smoother than raw CMC. Since less than a third of the sacrificial film was etched off, a surface roughness $< \pm 10 \mu \mathrm{m}$ is estimated for the technique to be practical. The surface roughness requirement for this technique is similar to that of photolithography, so the laser-pattering technique can be implemented where other issues such as chemical compatibility makes sensor fabrication a challenge. 
Since the surface roughness of EBC-CMC systems are still not the quality of polished metal components, and the existing surface roughness of CMC material is still unsuitable for fine-line $(<100 \mu \mathrm{m})$ patterned sensors, the challenge is, how to test the fabrication of thin film sensors on anticipated EBC-CMC surfaces. Typical tests for SiC-CMC compatibility are performed on commercial $\alpha$-SiC disk samples in present EBC material testing at GRC (Ref. 3). Therefore, in parallel to the material tests, $\alpha$-SiC disks (25 mm in diameter and $3 \mathrm{~mm}$ thick) polished to $\pm 10 \mu \mathrm{m}$ were used as substrates for the initial demonstration of a patterned sensor to be ultimately embedded in CMC systems. After some insulating oxide film failures during pre-treatment of the substrates, heat flux sensors were fabricated on the disk samples.

\section{Ceramic Heat Flux Sensors on $\alpha-S i C$}

The design for the heat flux sensors were based on the thermopile-based sensor shown in Figure 2 . The nanocomposite NiCoCrAlY:AlOx versus N:ITO as discussed earlier was selected as the thermocouple pair for the sensor. The substrate (the $\alpha$-SiC disk described earlier) was polished to $10 \mu \mathrm{m}$ roughness, then cleaned in an 1:1 solution of $\mathrm{H}_{2} \mathrm{SO}_{4}$ with $\mathrm{H}_{2} \mathrm{O}_{2}$ for $15 \mathrm{~min}$ ("p-clean") to remove surface contaminants. The substrate was annealed in air at $1100^{\circ} \mathrm{C}$ for $8 \mathrm{hr}$ to fully passivate the surface with an oxide, estimated to be $0.5 \mu \mathrm{m}$ thick.

Contact pads of platinum were sputtered deposited using shadow masks for large 2.5 by $5 \mathrm{~mm}^{2}$ patterns. For bonding the platinum to the oxide, a new multilayered adhesion scheme was used that first deposited an aluminum layer of $150 \AA$ followed immediately by $1 \mu \mathrm{m}$ of platinum in the vacuum sputtering unit. This bonding scheme was first used successfully with no film delamination in the heat flux sensors fabricated for the CEV TPS Heat Shield-toBackshell Interface Seals project mentioned earlier.

The nanocomposite elements were pattered via photolithography, and sputter deposited to $1 \mu \mathrm{m}$ thickness. Similarly, the N:ITO elements were pattered via photolithography to $2.5 \mu \mathrm{m}$ thickness. After each element, the sensor was vacuum annealed to $800{ }^{\circ} \mathrm{C}$ for $5 \mathrm{hr}$ to outgas and solidify the films. The sample appeared as shown in Figure 11 after the deposition and patterning of each element.

At this point, the nanocomposite was seen to be delaminating from the substrate during routine inspection after annealing. As seen in Figure 12, the delaminating films appear to be associated with pits and ridges in the substrate surface, which may be only part of the problem. The fact that the nanocomposite films failed, while the N:ITO did not, suggests that there may be a large CTE mismatch between the nanocomposite films and the substrate. Specifically, the NiCoCrAlY:AlOx is expected to have a CTE between 12 and $15 \times 10^{-6} \mathrm{~K}^{-1}$, where N:ITO is approximately $9 \times 10^{-6} \mathrm{~K}^{-1}$ and may more likely form an adhesion interface with the insulating oxide when annealed. Given the demonstrated capability of the nanocomposite film to adhere to other surfaces, present activity is directed toward surface and/or coating modification to improve the adherence of the nanocomposite film for this substrate.

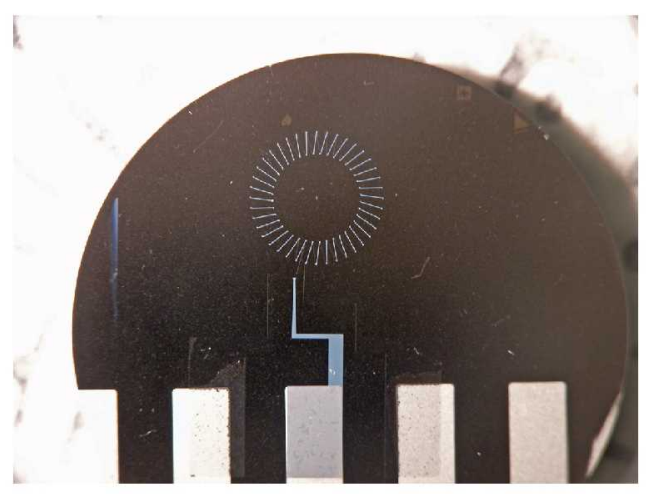

Figure 11.-Nanocomposite NiCoCrAIY:AIOxN:ITO heat flux sensor (Nanocomposite film is light, ITO film is dark) on a $25 \mathrm{~mm}$ diameter $\alpha$-SiC disk.

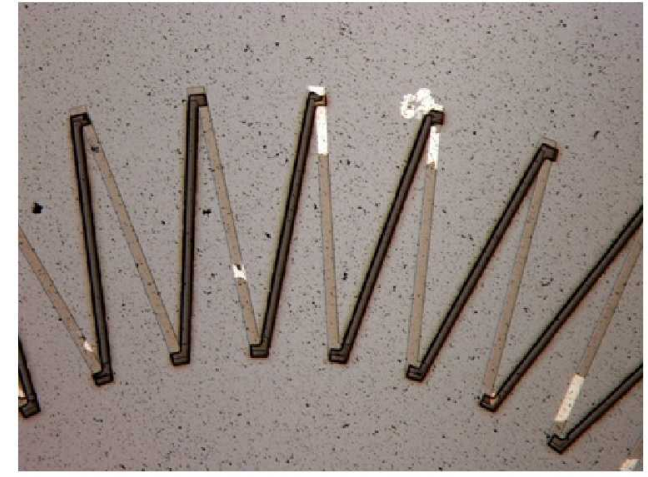

Figure 12.-Delaminating nanocomposite films (light) as seen under microscope after $800^{\circ} \mathrm{C}$ anneal, as well as the intact ITO films (dark). The film patterns are $50 \mu \mathrm{m}$ wide. 


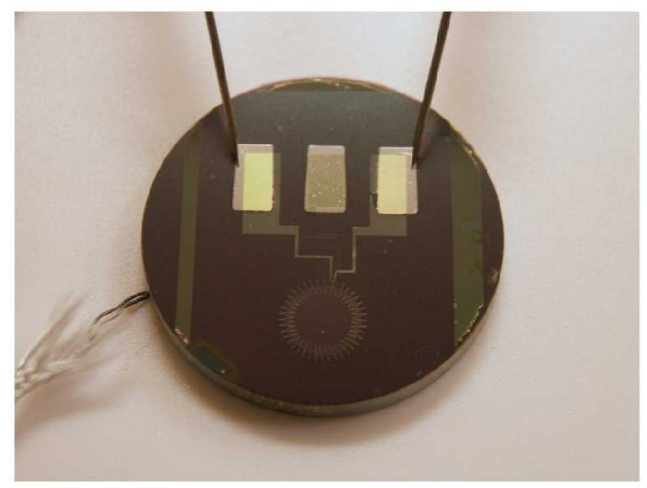

Figure 13.-Al:ZnO-N:ITO heat flux sensor on a $25 \mathrm{~mm}$ diameter $\alpha$-SiC disk during preliminary testing.

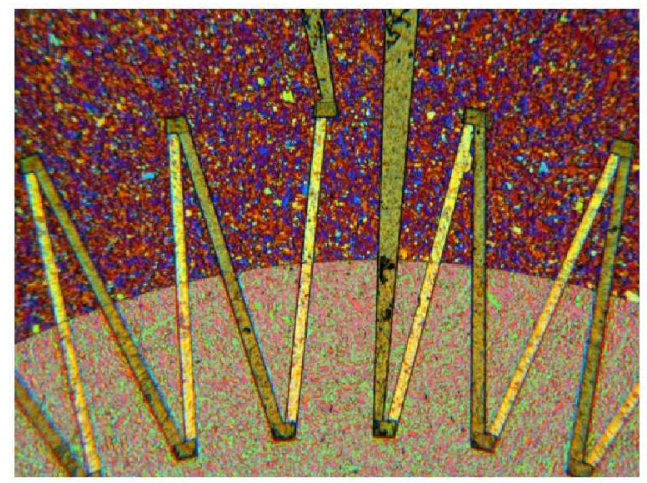

Figure 14.-Nanocomposite films (light), ITO films (dark), mullite insulation coating (lower) as seen under a microscope. The film patterns are $50 \mu \mathrm{m}$ wide.

An alternative to the nanocomposite of alumina and NiCoCrAlY is to use a nanocomposite of aluminum and zinc oxide (Al: $\mathrm{ZnO})$. This new nanocomposite is expected to have CTE of about $5 \times 10^{-6} \mathrm{~K}^{-1}$, a better match to SiC CMC. The new sensor was fabricated similarly as the first, with $2.2 \mu \mathrm{m} \mathrm{N}$ :ITO elements first deposited after vacuum annealing the platinum pads, then the $\mathrm{Al}: \mathrm{ZnO}$ elements were deposited (Ref. 18) to a thickness of $1 \mu \mathrm{m}$. Afterwards, $0.60 \mu \mathrm{m}$ of mullite was electron-beam deposited as the center insulating region. The final sensor appeared as shown in Figures 13 and 14. Note that the transparent nature of the films is the cause of the colors in Figure 14.

For the initial tests, the sensor was placed on a $250^{\circ} \mathrm{C}$ maximum hot plate with an estimated maximum heat flux of $0.22 \mathrm{~W} \cdot \mathrm{cm}^{-2}$, and the signal recorded through a data acquisition system. Then the sensor was placed on a $500{ }^{\circ} \mathrm{C}$ maximum hot plate with an estimated maximum heat flux of $0.20 \mathrm{~W} \cdot \mathrm{cm}^{-2}$, and the output recorded again through the same data acquisition system for comparison. After smoothing the signals using a moving average over $170 \mathrm{sec}$, a sensitivity corresponding to $0.06 \pm 0.02 \mu \mathrm{V} \cdot\left(\mathrm{W} \cdot \mathrm{cm}^{-2}\right)^{-1}$ is seen as shown in Figure 15 (a) and (b). The resulting signal is considered accurate to $\pm 0.0035 \mu \mathrm{V}$. This represents the first thin film heat flux sensor pattern deposited and operated on such a surface.

A determination of the output of the $\mathrm{Al}: \mathrm{ZnO}$ versus ITO thermocouple can be deduced from this preliminary result. Considering that the $0.60 \mu \mathrm{m}$ mullite layer has a bulk thermoconductivity of approximately (Ref. 11) $5.5 \mathrm{~W} \cdot(\mathrm{m} \cdot \mathrm{K})^{-1}$, for $0.2 \mathrm{~W} \cdot \mathrm{cm}^{-2}\left(2000 \mathrm{~W} \cdot \mathrm{m}^{-2}\right)$ a temperature gradient of $220 \mu \mathrm{K}$ is generated to produce $0.012 \mu \mathrm{V}$ signal output. The thermopile has 40 pairs, so a single $\mathrm{Al}: \mathrm{ZnO}$ versus N:ITO thermocouple junction has a thermoelectric power of approximately $14 \mu \mathrm{V} \cdot \mathrm{K}^{-1}$. In comparison, an ANSI-standard Type R thermocouple junction has an output of $8.5 \mu \mathrm{V} \cdot \mathrm{K}^{-1}$ at $200^{\circ} \mathrm{C}$. 


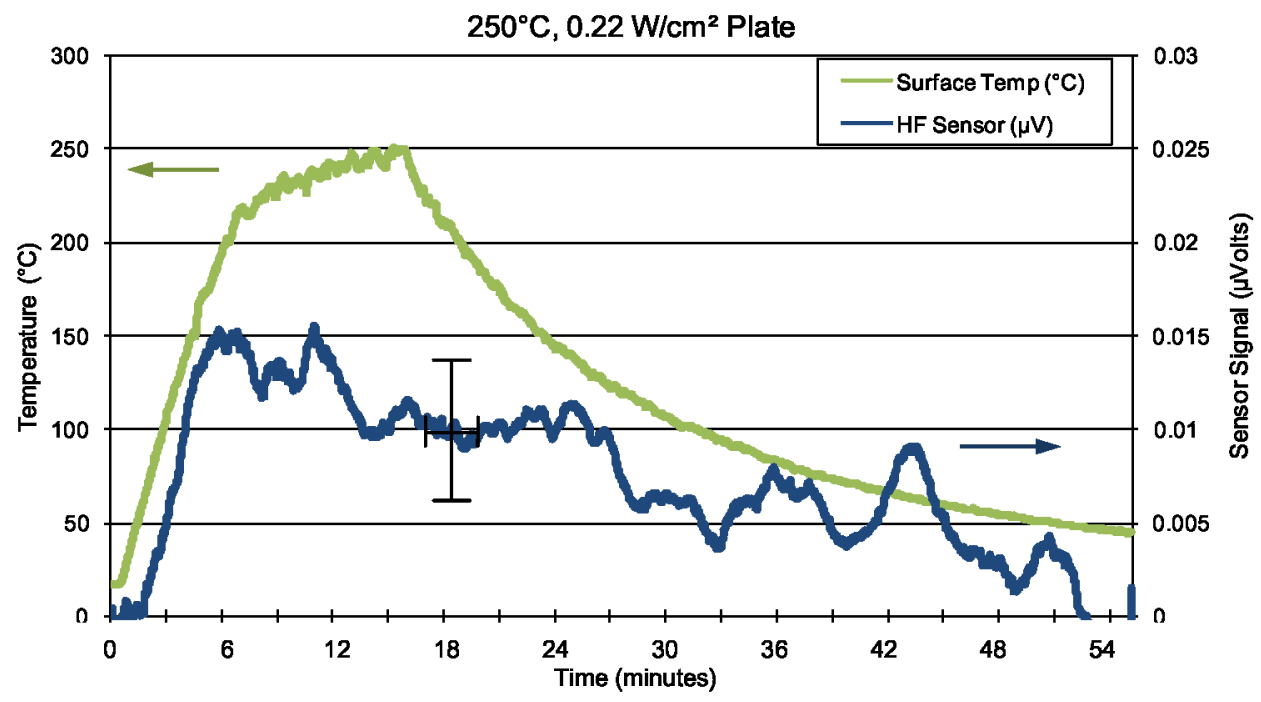

(a)

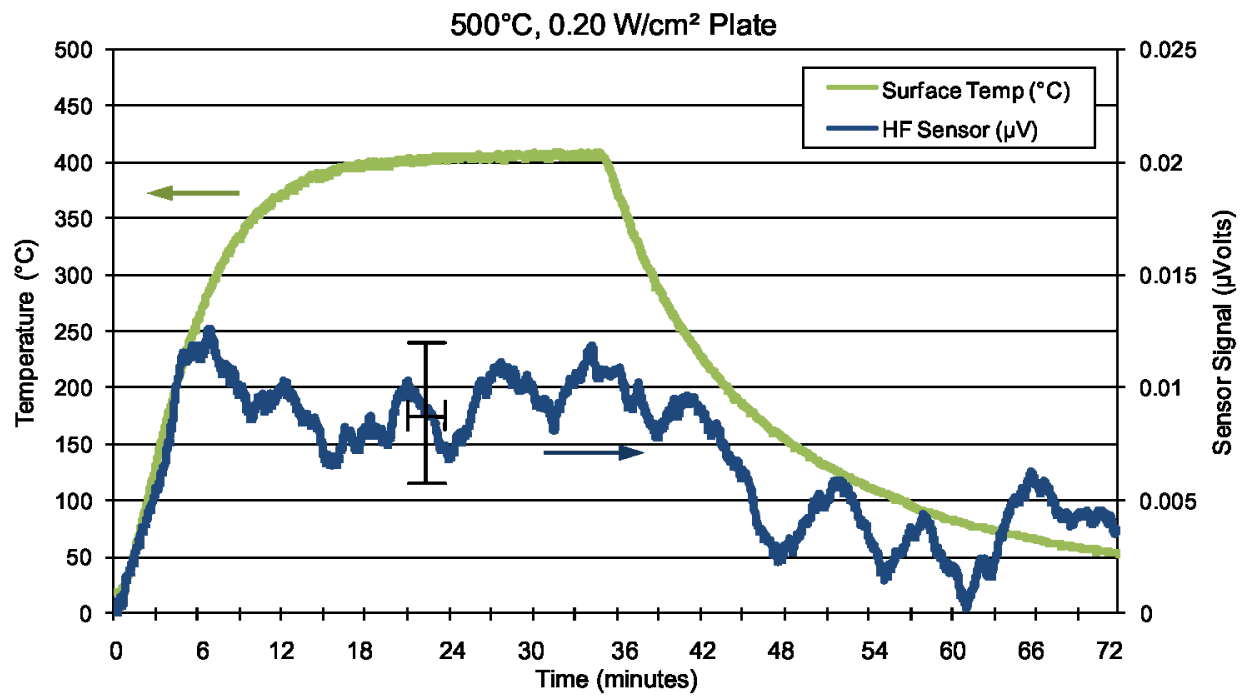

(b)

Figure 15.-Response of Al:ZnO-N:ITO heat flux sensor tracked with surface temperature of the hot plate surfaces of: (a) $0.22 \mathrm{~W} \cdot \mathrm{cm}^{-2}, 250^{\circ} \mathrm{C}$ maximum and (b) $0.20 \mathrm{~W} \cdot \mathrm{cm}^{-2}$, $500^{\circ} \mathrm{C}$ maximum. Representative error bars are shown on each graph.

\section{Conclusions and Future Work}

In response to an increased demand for in-situ measurement of high temperature heat flux, GRC is applying thin film high temperature measurement technology to aerospace systems in development. The $1700{ }^{\circ} \mathrm{C}$ EBC-CMC systems under development at GRC require such sensors to allow a more complete characterization of the systems. To satisfy the conditions of the EBC-CMC system, GRC undertook an examination of novel approaches to fabricating ceramic film heat flux sensors.

The properties of silicides and conductive oxides were examined for suitability as components for a thermopile heat flux sensor. The $\mathrm{CrSi}$ and $\mathrm{MoSi}$ samples demonstrated the need for oxidation protection for the silicides to be part of a usable thin film sensor. The signal from a thermocouple of a nanocomposite film of NiCoCrAlY and alumina versus N:ITO film was examined and found to have suitable high output over a large temperature range. 
The rough nature of the $\mathrm{CMC}$ and the porous nature of the $\mathrm{EBC}$ posed a significant challenge for patterning the fine features required. Laser-patterned sensors as a direct-write method of masking for fine-line films had success on smooth substrates, but not on the rough EBC-CMC. Laser-patterning still can be used as a method of tracing through ablation an outline of a sensor pattern in an existing film, with feature widths greater than $30 \mu \mathrm{m}$, similar in resolution of the photolithographic technique but on surfaces that photolithographic chemicals could not be used.

As the roughness of CMC components progress towards smoother surfaces, similar to polished metal components in the future, substrates of $\alpha-\mathrm{SiC}$ were used to simulate a $10 \mu \mathrm{m} \mathrm{CMC} \mathrm{component} \mathrm{surface.} \mathrm{A} \mathrm{heat} \mathrm{flux}$ sensor was fabricated on the substrate forming a complete sensor structure. However, upon annealing, it appears that the CTE mismatch of the nanocomposite NiCoCrAlY/alumina is too high to produce a stable, adherent coating. A new heat flux sensor was fabricated using an alternative nanocomposite of aluminum and zinc oxide. From preliminary data, the new sensor has a response of $0.06 \pm 0.02 \mu \mathrm{V} \cdot\left(\mathrm{W} \cdot \mathrm{cm}^{-2}\right)^{-1}$, and more extensive testing is planned for the future.

\section{References}

1. LaChapelle, D.G., Noe, M.E., Edmondson, W.G., Stegemiller, H.J., Steibel, J.D., and Chang, D.R., "CMC Materials Applications to Gas Turbine Hot Section Components," 34th AIAA/ASME/SAE/AASEE Joint Propulsion Conference \& Exhibit, July 13-15,1998, Cleveland, OH, AIAA-1998-3266.

2. Levine, S.R., Calomino, A.M., Verrilli, M.J., Thomas, D.J., Halbig, M.C., Opila, E.J., and Ellis, J.R., "Ceramic Matrix Composites (CMC) Life Prediction Development-2003," NASA/TM-2003-212493 (August 2003).

3. Zhu, D., Bansal, N.P., and Miller, R.A., "Thermal Conductivity and Stability of $\mathrm{HfO}_{2}-\mathrm{Y}_{2} \mathrm{O}_{3}$ and $\mathrm{La}_{2} \mathrm{Zr}_{2} \mathrm{O}_{7}$ Evaluated for $1650{ }^{\circ} \mathrm{C}$ Thermal/Environmental Barrier Coating Applications," NASA/TM-2003-212544, ARL-TR-3093 (November 2003).

4. Wrbanek, J.D., and Fralick, G.C., "Thin Film Physical Sensor Instrumentation Research and Development at NASA Glenn Research Center," NASA/TM-2006-214395 (September 2006).

5. Lei, J.F., and Will, H.A., "Thin-film thermocouples and strain-gauge technologies for engine applications," Sensors and Actuators A 65 (1998) 187-193.

6. Fralick, G.C., Wrbanek, J.D., and Blaha, C.A., "Thin Film Heat Flux Sensor of Improved Design," NASA/TM-2002-211566 (September 2002).

7. Cho, C.S., Fralick, G.C., and Bhatt, H.D., "Steady State and Frequency Response of a Thin Film Heat Flux Gauge," Journal of Spacecraft and Rockets 34 (6) (1997) 792-798.

8. Wilson, S.D., Fralick, G.C., Wrbanek, J.D., and Sayir, A., "Fabrication and Testing of a Thin-Film Heat Flux Sensor for a Stirling Convertor," Proceedings of the Seventh International Energy Conversion Engineering Conference, August 2-6, 2009, Denver, Colorado (IECEC 2009). AIAA-2009-4581, NASA/TM-2010216063 (January 2010).

9. Bansal, N.P., "Mechanical properties of Hi-Nicalon fiber-reinforced celsian composites after high-temperature exposures in air," J. Eur. Ceram. Soc. (2008), doi:10.1016/j.jeurceramsoc.2008.06.023.

10. DiCarlo, J.A., Yun, H.-M., Morscher, G.N., and Bhatt, R.T.: "SiC/SiC Composites for $1200{ }^{\circ} \mathrm{C}$ and Above," NASA/TM-2004-213048 (November 2004).

11. Bradstreet, S.W., "Oxide Ceramics," Chapter 8 in High Temperature Materials and Technology, edited by I.E. Campbell and E.M. Sherwood (Wiley, 1967) pp. 235-303.

12. Wrbanek, J.D., Fralick, G.C., and Hunter, G.W., "Thin Film Ceramic Strain Sensor Development for Harsh Environments: Interim Report on Identification of Candidate Thin Film Ceramics to Test for Viability for Static Strain Sensor Development," NASA/TM-2006-214466 (December 2006).

13. Campbell, D.S., "Mechanical Properties of Thin Films," Handbook of Thin Film Technology, edited by L.I. Maissel and R. Glang (McGraw-Hill, 1970) pp. 12-3 to 12-50.

14. Mattox, D.M, "Thin Film Metallization of Oxides in Microelectronics," Thin Solid Films 18 (1973) 173-186.

15. Wrbanek, J.D., Fralick, G.C., Farmer, S.C., Sayir, A., Blaha, C.A., and Gonzalez, J.M., "Development of Thin Film Ceramic Thermocouples for High Temperature Environments," NASA/TM-2004-213211, AIAA-2004 3549 (August 2004). 
16. Gregory, O.J., Busch, E., and Fralick, G.C., "Thermoelectric Properties of Ceramic Thin Film Thermocouples," 52nd International Instrumentation Symposium, May 7-11, 2006, Cleveland, Ohio, TP06IIS037.

17. Martin, L.C., and Will, H.A., "Testing of Thin Film Thermocouples on Ceramic Matrix Composites in a Burner Rig," NASA CP-10178 (1995) Paper 39.

18. Al:ZnO depositions were performed at the University of Rhode Island as part of NASA Grant NNCO5GA67G sponsored by the NASA AAD project. 


\begin{tabular}{|c|c|c|}
\hline \multicolumn{2}{|c|}{ REPORT DOCUMENTATION PAGE } & $\begin{array}{l}\text { Form Approved } \\
\text { OMB No. 0704-0188 }\end{array}$ \\
\hline \multicolumn{3}{|c|}{$\begin{array}{l}\text { The public reporting burden for this collection of information is estimated to average } 1 \text { hour per response, including the time for reviewing instructions, searching existing data sources, gathering and maintaining the } \\
\text { data needed, and completing and reviewing the collection of information. Send comments regarding this burden estimate or any other aspect of this collection of information, including suggestions for reducing this } \\
\text { burden, to Department of Defense, Washington Headquarters Services, Directorate for Information Operations and Reports (0704-0188), 1215 Jefferson Davis Highway, Suite } 1204 \text {, Arlington, VA 22202-4302. } \\
\text { Respondents should be aware that notwithstanding any other provision of law, no person shall be subject to any penalty for failing to comply with a collection of information if it does not display a currently valid OMB } \\
\text { control number. } \\
\text { PLEASE DO NOT RETURN YOUR FORM TO THE ABOVE ADDRESS. }\end{array}$} \\
\hline $\begin{array}{l}\text { 1. REPORT DATE (DD-MM-YYYY) } \\
01-03-2010\end{array}$ & $\begin{array}{l}\text { 2. REPORT TYPE } \\
\text { Technical Memorandum }\end{array}$ & 3. DATES COVERED (From - To) \\
\hline \multirow{3}{*}{\multicolumn{2}{|c|}{$\begin{array}{l}\text { 4. TITLE AND SUBTITLE } \\
\text { Thin Film Heat Flux Sensor Development for Ceramic Matrix Composite (CMC) Systems }\end{array}$}} & 5a. CONTRACT NUMBER \\
\hline & & 5b. GRANT NUMBER \\
\hline & & 5c. PROGRAM ELEMENT NUMBER \\
\hline \multirow{3}{*}{\multicolumn{2}{|c|}{$\begin{array}{l}\text { 6. AUTHOR(S) } \\
\text { Wrbanek, John, D.; Fralick, Gustave, C.; Hunter, Gary, W.; Zhu, Dongming; Laster, Kimala, } \\
\text { L.; Gonzalez, Jose, M.; Gregory, Otto, J. }\end{array}$}} & 5d. PROJECT NUMBER \\
\hline & & 5e. TASK NUMBER \\
\hline & & $\begin{array}{l}\text { 5f. WORK UNIT NUMBER } \\
\text { WBS 984754.02.07.03.16.03 }\end{array}$ \\
\hline \multicolumn{2}{|c|}{$\begin{array}{l}\text { 7. PERFORMING ORGANIZATION NAME(S) AND ADDRESS(ES) } \\
\text { National Aeronautics and Space Administration } \\
\text { John H. Glenn Research Center at Lewis Field } \\
\text { Cleveland, Ohio } 44135-3191\end{array}$} & $\begin{array}{l}\text { 8. PERFORMING ORGANIZATION } \\
\text { REPORT NUMBER } \\
\text { E-17197 }\end{array}$ \\
\hline \multirow{2}{*}{\multicolumn{2}{|c|}{$\begin{array}{l}\text { 9. SPONSORING/MONITORING AGENCY NAME(S) AND ADDRESS(ES) } \\
\text { National Aeronautics and Space Administration } \\
\text { Washington, DC 20546-0001 }\end{array}$}} & $\begin{array}{l}\text { 10. SPONSORING/MONITOR'S } \\
\text { ACRONYM(S) } \\
\text { NASA }\end{array}$ \\
\hline & & $\begin{array}{l}\text { 11. SPONSORING/MONITORING } \\
\text { REPORT NUMBER } \\
\text { NASA/TM-2010-216216 }\end{array}$ \\
\hline \multicolumn{3}{|c|}{$\begin{array}{l}\text { 12. DISTRIBUTION/AVAILABILITY STATEMENT } \\
\text { Unclassified-Unlimited } \\
\text { Subject Categories: } 35 \text { and } 24 \\
\text { Available electronically at http://gltrs.grc.nasa.gov } \\
\text { This publication is available from the NASA Center for AeroSpace Information, 443-757-5802 }\end{array}$} \\
\hline
\end{tabular}

\section{SUPPLEMENTARY NOTES}

\section{ABSTRACT}

The NASA Glenn Research Center (GRC) has an on-going effort for developing high temperature thin film sensors for advanced turbine engine components. Stable, high temperature thin film ceramic thermocouples have been demonstrated in the lab, and novel methods of fabricating sensors have been developed. To fabricate thin film heat flux sensors for Ceramic Matrix Composite (CMC) systems, the rough and porous nature of the CMC system posed a significant challenge for patterning the fine features required. The status of the effort to develop thin film heat flux sensors specifically for use on silicon carbide (SiC) CMC systems with these new technologies is described. 15. SUBJECT TERMS

Thin films; Ceramic matrix composites; Sensor; High temperature; Ceramics

\begin{tabular}{|l|l|l|l|l|l|}
\hline \multicolumn{2}{|l|}{ 16. SECURITY CLASSIFICATION OF: } & $\begin{array}{l}\text { 17. LIMITATION OF } \\
\text { ABSTRACT }\end{array}$ & $\begin{array}{l}\text { 18. NUMBER } \\
\text { OF } \\
\text { PAGES }\end{array}$ & $\begin{array}{l}\text { 19a. NAME OF RESPONSIBLE PERSON } \\
\text { STI Help Desk (email:help@sti.nasa.gov) }\end{array}$ \\
\cline { 1 - 2 } $\begin{array}{l}\text { a. REPORT } \\
\text { U }\end{array}$ & $\begin{array}{l}\text { b. ABSTRACT } \\
\text { U }\end{array}$ & $\begin{array}{l}\text { C. THIS } \\
\text { PAGE } \\
\text { UU }\end{array}$ & UU & 16 & $\begin{array}{l}\text { 19b. TELEPHONE NUMBER (include area code) } \\
\text { 443-757-5802 }\end{array}$ \\
\hline
\end{tabular}



